\title{
Stratigraphy of Palaeocene phosphate pelagic stromatolites (Prebetic Zone, SE Spain)
}

\author{
B. Chacón· Javier Martín-Chivelet
}

\begin{abstract}
The hemipelagic domain of the ancient southern continental margin of Iberia is home to a strongly condensed pelagic succession (6-15 $\mathrm{cm}$ thick) characterized by the presence of phosphate stromatolites. This succession, probably generate in the slope of the continental margin, records a period of some $9 \mathrm{Ma}$, corresponding to the latest Maastrichtian to Late Thanetian interval. A microstratigraphical analysis allows for characterizing and biostratigraphically dating six successive developmental stages in the succession, which outline the main environmental evolution of the depositional setting. The first of them determined the generation of a submarine hardground during the latest Maastrichtian to earliest Danian interval. The other five are represented by five successive microstratigraphical, unconformity-bounded, genetic units, respectively EarlyMiddle Danian, Late Danian-Early Selandian, in tra-Selandian, Late Selandian-Early Thanetian, and Middle-?Late Thanetian in age. The three oldest units are characterized by the accretion of phosphate stromatolites, favoured by very low rates of pelagic sedimentation and by a microbially mediated extra input of phosphate. The two youngest units are dominated by carbonate deposition, which has always taken place at very low rates. Condensed sedimentation was abruptly interrupted at the end of the Palaeocene (?latest Thanetian), when the condensed succession and its hosting substrate were gravitationally slumped and re-
\end{abstract}

\section{B. Chacón}

Repsol YPF, Paseo de la Castellana 280,

28046 Madrid, Spain

J. Martín-Chivelet ( $\square)$

Dpto. de Estratigrafía, Instituto de Geología Económica

(CSIC-UCM), Facultad de Ciencias Geológicas,

Universidad Complutense, 28040 Madrid, Spain

e-mail: j.m.chivelet@geo.ucm.es deposite at the base of the slope in the form of a megadebris flow that can be now observed in Sierra de Aixorta (Alicante, SE Spain). The Aixorta pelagic phosphatic stromatolites are among the youngest ever described, and their existence suggests that the oceanographic conditions necessary for their development prevailed during most of the Palaeocene, but disappeared during the Late Selandian, never to return.

Keywords Condensed sedimentation - Deep-water stromatolites $\cdot$ Phosphate $\cdot$ Palaeocene $\cdot$ Prebetic $\cdot$ Spain

\section{Introduction}

Phosphatic stromatolites, generated by the authigenic phosphatization of microbial mats on ancient pelagic seafloors, are striking deposits with no known modern analogues. They are relatively abundant in the open-marine carbonate sequences of the Tethys Realm, generated essentially during the Jurassic and Cretaceous. These stromatolites commonly occur in association with submarine hiatuses and hardgrounds, and appear usually to have developed on pelagic swells at water depths of several hundreds of metres, in aphotic settings (Martín-Algarra and SánchezNavas 2000) and under oxic-suboxic conditions (Krajewski et al. 2000). Their genesis seems to be related to major palaeoceanographic changes causing rapid sea-level rises, carbonate platform destruction and water-column europhication (e.g., Krajewski et al. 1994, 2000; Föllmi 1989, 1996; Martín-Algarra and Sánchez-Navas 1995, 2000; Sánchez-Navas and Martín-Algarra 2001).

Recent work on these phosphate deposits has concentrate on their geochemical, mineralogical and microstructural features, thus allowing the examination of their 
microbial origin (e.g., Krajewski et al. 2000; MartínAlgarra and Sánchez-Navas 2000). These biosedimentary concretions grew at the sediment-water interface in openmarine settings characterized by particular sedimentological and hydrochemical conditions, including the low input of sedimentary material and a considerable influx of dissolved phosphorous and other ions. The stromatolites accreted by bacterially mediated precipitation of authigenic minerals, by trapping and binding of fine-grained particles, and, in some cases, also by encrusting organisms.

Despite noticeable advances in the knowledge of the genesis and composition of these deep-water stromatolites, little attention has been paid to their microstratigraphy. Stromatolite internal lamination, micro-sequences and micro-unconformities reveal that sediment-starved openmarine settings were sensible to subtle changing sedimentary conditions controlled by the evolution of physicochemical parameters both in the productive surface waters and at the sediment-water interface. Also, although there is a general agreement on the relatively slow rates of stromatolite growth in those settings (e.g., Van Capellen and Berner 1991; Böhm and Brachert 1993; Föllmi 1996), poor knowledge exists on the duration of the phosphatic stromatolite sequences and on their ultimate causes.

Resolving these problems requires microstratigraphical studies including accurate recognition and correlation of genetic micro-units and their bounding surfaces, along with detailed micropalaeontological identification of microfossils trapped within stromatolitic sequences. This paper focuses on this task by discussing, from a microstratigraphical perspective, a condensed Palaeocene succession rich in phosphate open-marine stromatolites, with the aim of characterizing and dating the main phases of its development. We hope the study will help in the understanding of similar formations of different age and in different basins.

\section{Palaeogeographic and stratigraphic framework}

The studied condensed stratigraphic section is located in the Sierra de Aixorta (Province of Alicante, SE Spain) near the town of Callosa d'Ensarriá (Fig. 1). From a geological point of view, this area is included in the Prebetic Zone, a broad Alpine tectonic unit that corresponds to the outer
Fig. 1 Geological and geographical location of the studied outcrop in the hemipelagic domain of the Prebetic Zone

(External Betics, SE Spain).

Other localities with outcrops of latest Cretaceous and Palaeocene sedimentary rocks mentioned in the text are also shown

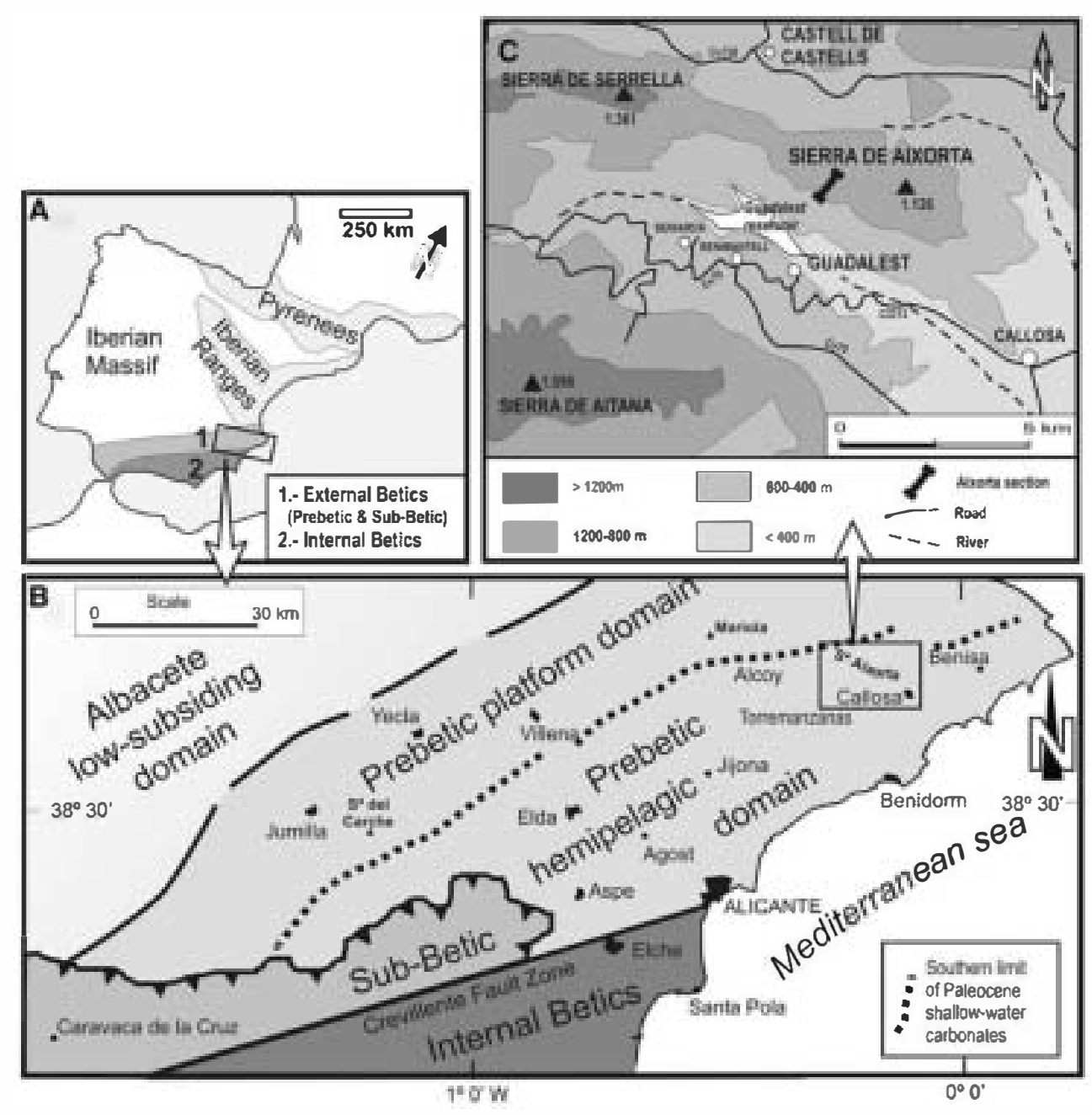


portion of the foreland fold-and-thrust belt of the Betic Cordillera. This unit includes a thick para-autochthonous sedimentary cover of Mesozoic-Cenozoic age, which became detached from the Variscan basement along with Upper Triassic evaporites during the main orogenic stage, in the Miocene. The sedimentary cover was originally deposite in the southern continental margin of Iberia, a basin derived from the break-up and divergence of Africa and Europe since the Triassic, and which underwent transition from a passive to a convergent margin during the latest Cretaceous and Early Palaeogene (Martín-Chivelet et al. 2002; Martín-Chivelet and Chacón 2007).

In the studied area, the uppermost Cretaceous and the Lower Palaeogene consist of hemipelagic limestones and marls deposited in the proximal zone of the deep marine environments of the southern continental margin of Iberia. In the Sierra Aixorta, the Campanian to Palaeocene succession is represented by a series of deposits some $155 \mathrm{~m}$ thick (Chacón 2002) consisting of four main stratigraphic intervals. From the base to the top these are: (1) a quite homogenous marly carbonate unit with some calcarenitic intercalations (Carche Formation, $93 \mathrm{~m}$ thick) Campanian to mid-Maastrichtian in age; (2) a marly unit with some thin intercalations of limestones (Raspay Fm., $50 \mathrm{~m}$ thick), Late Maastrichtian in age; (3) a marly carbonate unit (Agost Fm., $5 \mathrm{~m}$ thick), Danian to Early Selandian in age; and (4) an olisthostromic unit (5-8 $\mathrm{m}$ thick) consisting of a chaotic accumulation of limestone blocks, marls and sandy limestones ranging from Maastrichtian to Early Ilerdian in age. This chaotic unit, which was probably laid down as a mega-slump at the end of the Palaeocene (see details below), includes large boulders (Figs. 2 and 3) which contain the hardground and stromatolitic crust forming the subject of this study. It should be noted, therefore, that these stromatolites did not develop in the same place as the underlying Late Cretaceous succession, but in a shallower area of the basin, probably the talus, from where they were displaced and re-deposited. The lithostratigraphic units adopted in this paper are those proposed by Chacón and Martín-Chivelet (2005).

This stromatolitic crust in the Aixorta succession was previously documented by Company et al. (1982), and described by Vera and Martín-Algarra (1994) and Martín-Algarra and Sánchez-Navas (2000). These papers give a broad stratigraphic adscription of the crust (at ibuted to the CretaceousPalaeocene boundary) and include an excellent background of knowledge about its mineralogical and textural features.

\section{Methods}

The microstratigraphical analysis of the condensed section (and particularly of its stromatolitic accretions) was essentially performed on the basis of petrographic observations

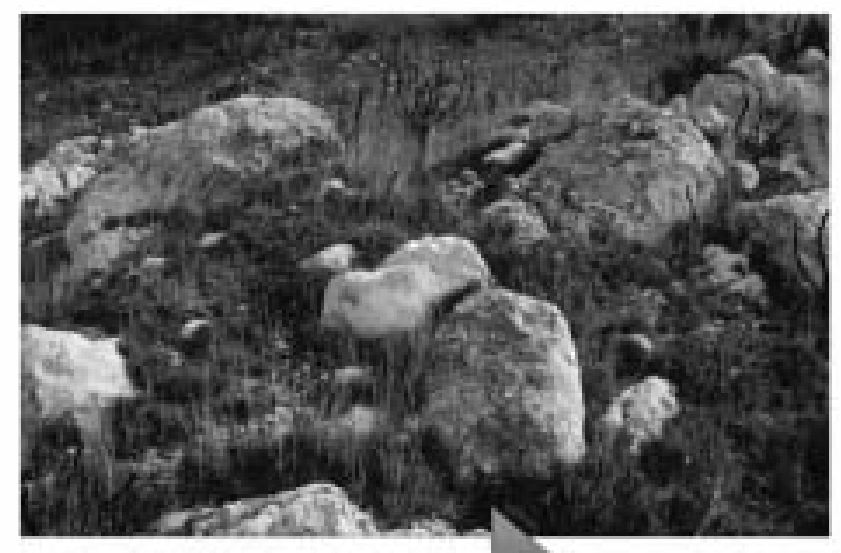

\section{AIXORTA SECTION}

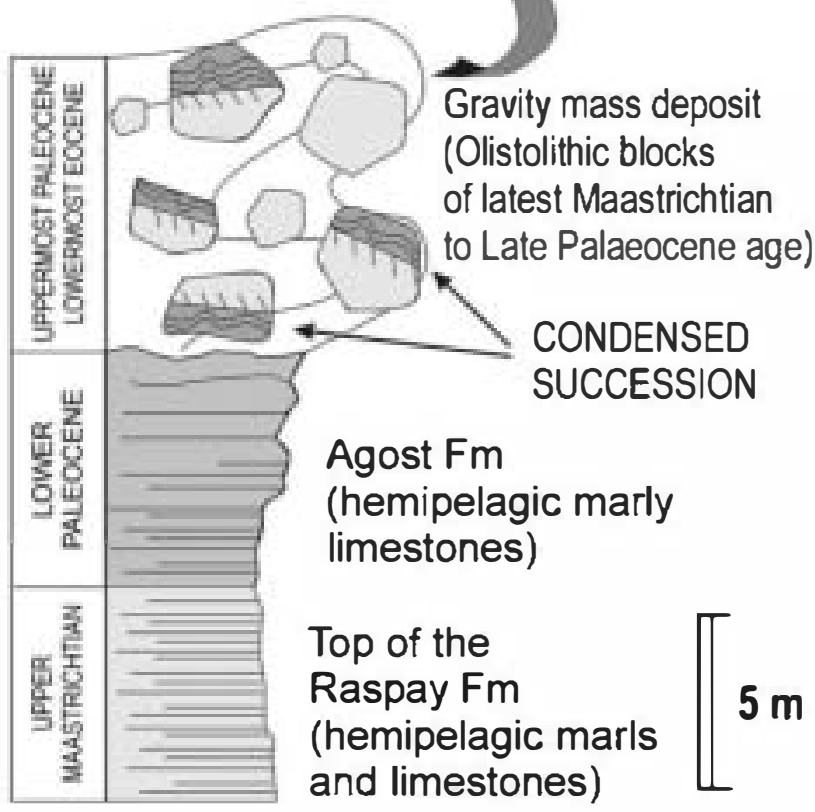

Fig. 2 Simplified stratigraphic log of the uppermost MaastrichtianLower Eocene sequence in the Sierra de Aixorta. The condensed succession of latest Maastrichtian-Late Palaeocene age analysed in this paper was found in the olistolithic blocks included in a gravity-mass chaotic unit laid down at the end of the Palaeocene or the onset of the Eocene. See text for details

from 50 thin sections and 20 polished sections. Samples were cut parallel, perpendicular and obliquely to the stromatolitic crust in order to observe the patterns of tbreedimensional growth, and to identify, correlate, map, and characterize genetic microstratigraphical units. A careful search was made for planktonic foraminifers trapped in the stromatolites with the aim of chronobiostratigraphically dating the different microstratigraphical units. The study was also supported by a combination of complementary techmiques including fluorescence microscopy, scanning electron microscopy (SEM; using a JEOL JM-6400 apparatus), electron probe microanalysis (EPMA; using a JEOL JXA-8900M apparatus), and X-ray diffraction analyses (using a Philips PW 1130/90 apparatus). 

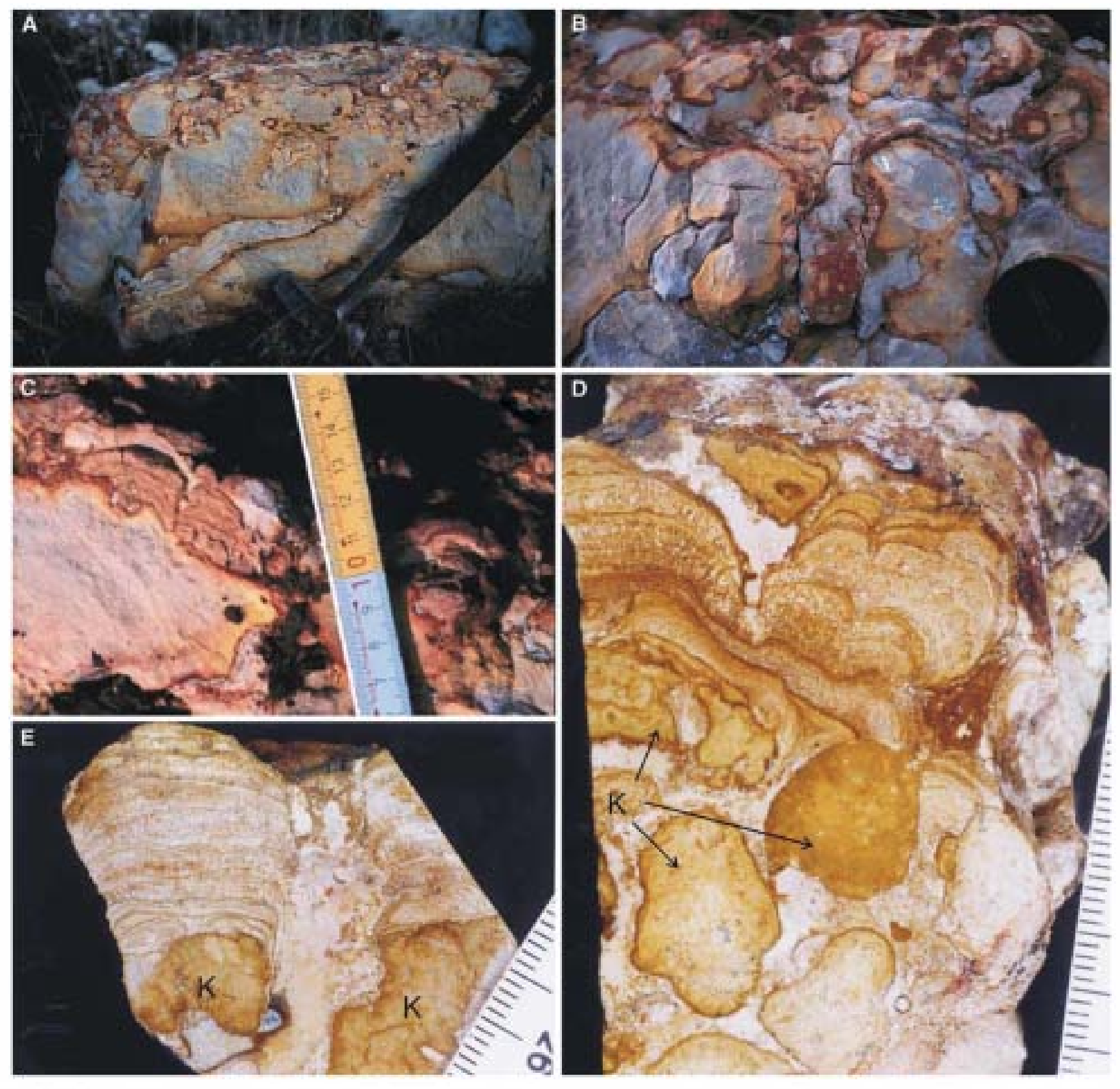

Fig. 3 Macro- and meso-scale details of the hardground developed at the top of the uppermost Maastrichtian deposits, and of the overlying stromatolitic crust. a-c Field photographs of the discontinuity showing the intensely burrowed, iron-enriched, lithified and bored surface covered by the stromatolitic crust. $\mathbf{a}-\mathbf{b}$ show endostromatolites coating the

\section{Microstratigraphy and development of the condensed succession}

The condensed section (including the phosphatic stromatolites) forms a 6-15-cm-thick succession (Fig. 3a-g), developed over hemipelagic carbonates of latest Maas tichtian age. These carbonates, located immediately below the condensed succession, consist of slightly argillaceous to pure limestone, pale greyish coloured, that can be framed within

uppermostcentimetres of the inner walls of the bioturbations in the Upper Maastrichtian deposits. d-e Details of polished slabs. Note that the uppermost Cretaceous limestones $(K)$ were intensely ferruginized and nodulized before being covered by stromatolitic laminations

the uppermost part of the Raspay Formation (Martín-Chivelet 1994; Chacón and Martín-Chivelet 2005). Texturally they are fine-grained wackestones, which contain rich associations of planktonic foraminifers, some benthonic foraminifers, calcispheres, and ostracods (Fig. 4). The Raspay Fm. is regionally $7-20 \mathrm{~m}$ thick, and typically contains marls and marly limestones, deposited in a hemipelagic setting, under water-depths of $200 \mathrm{~m}$ or greater according to the recognized benthonic foraminiferal assemblages (Chacón 2002; 


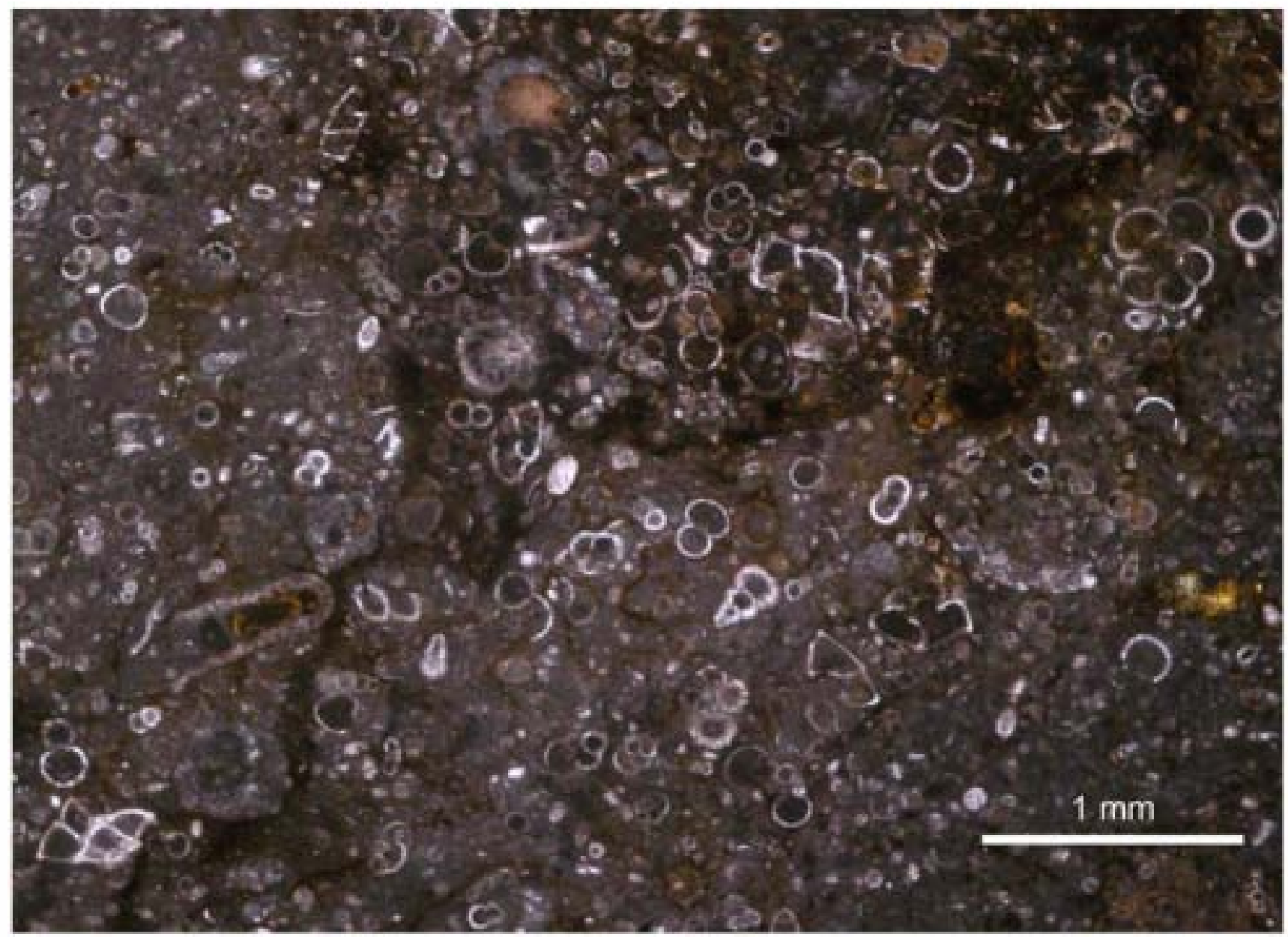

Fig. 4 Microfacies of Upper Maastichtian hemipalgic carbonates corresponding to the top of the Raspay Formation. These are the underlying deposits of the Aixorta condensed section (uppermost Maastrichtian to Selandian). Thin section microphotograph taken under transmitted light

Martín-Chivelet and Chacón 2007). The age of the Raspay Fm. is late to latest Maastrichtian, as it includes the upper part of the Gansserina gansseri Zone and the Abathomphalus mayaroensis Zone (Chacón et al. 2004).

In the analyzed outcrop, the condensed succession is clearly distinguishable by its prominent orange to dark-red colour (which contrasts with the underlying pale-grey limestone, see Fig. 3), by the existence of laminated stromatolitic structures, and by the presence of borings and other biogenic structures. On the basis of a detailed microstratigraphical analysis, the following episodes of development have been distinguished.

Hardground development (latest Maastrichtian-earliest Danian)

The base of the condensed section is represented by a spectacular hardground. As indicated above, this is developed at the top of Raspay Fm. (uppermost Maastrichtian). The hardground consists of an intensely burrowed, ironenriched, lithified and bored surface that was colonized by some epifaunal organisms. No evidence of shallow-water faunas, photosynthetic algae, or subaerial exposure was found on the surface. In detail, the hardground suffered the following processes, ordered chronologically (Fig. 5a-d):

1. Burrowing and nodulization: The uppermost decimetres of the underlying limestone show a dense threedimensional network of bioturbations (burrows), which are included in the Thalassinoides ichmofacies. The pervasive borrowing suggests an abrupt reduction in the sedimentation rate. This biological activity would also explain the moderate to intense, macroscopic, early nodulization shown by the latest Maastrichtian facies.

2. Early lithification and boring: With the halt of sedimentation the carbonate underwent early lithification and boring. Borings, smaller and simpler in shape than the burrows, are confined to the uppermost centimetres of the limestone.

3. Iron and phosphate enrichment: The latest Cretaceous sediments are fine-grained wackestones which consist of nearly pure carbonate. Some fine argillaceous and 


\section{A}

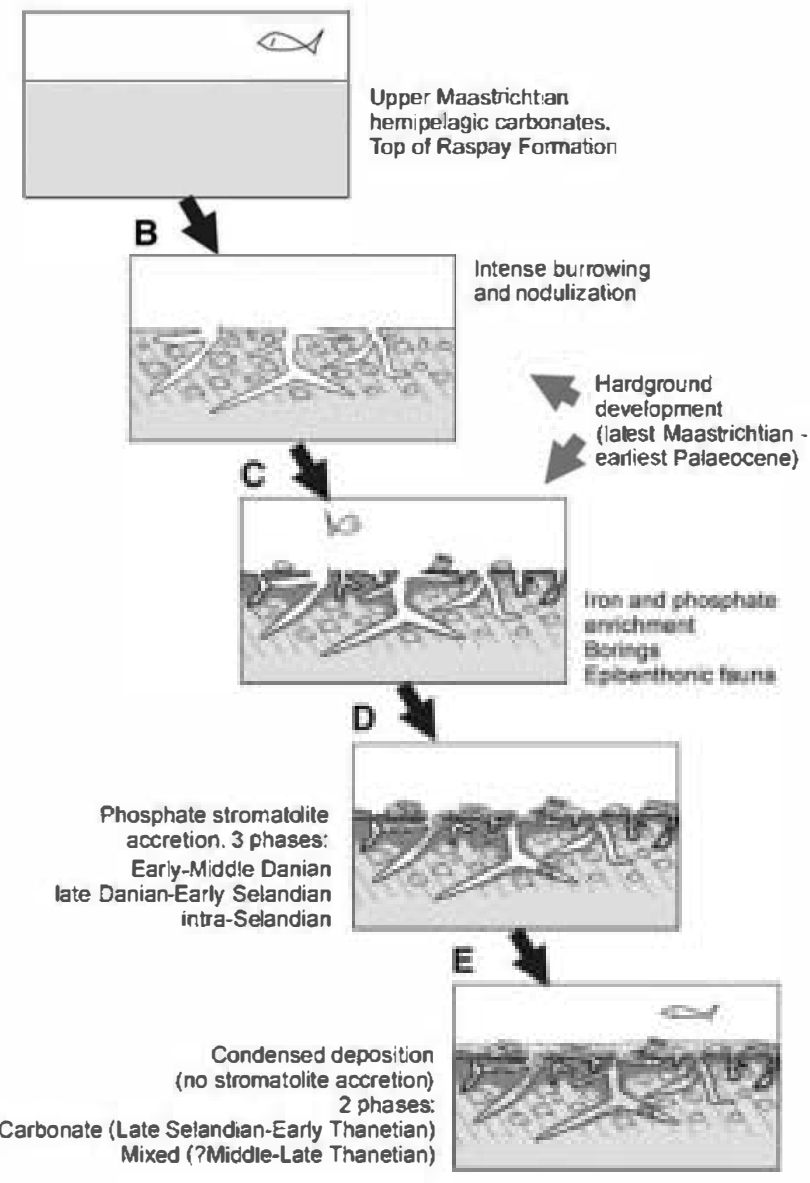

Fig. 5 Summary chart explaining the different stages of the development of the hardground and the stromatolitic accretions. a Pause in sedimentation and intensive development of burrows (latest Maasrichtian). b Early diagenesis with lithification, and iron enrichment (latest Maastrichtian-earliest Danian). c Borings in the lithified deposits, iron enrichment, and encrustation by epizoans (latest Maastrichvan-earliest Danian). d Growth of stromatolitic laminations spreading over the irregular hardground surface (Early Danian). e Partial filling of the bioturbations with very fine biomicritic sediments: stromatolitic accretions (Middle Danian-Early Thanetian) separate the different infilling episodes. $\mathbf{f}$ Total filling of the bioturbations and the hollows between the stromatolitic constructions

silty material has been recognized in some of the samples. The very top of these carbonates show some enrichment in iron oxides and phosphate.

4. Colonization of the surface by epibenthonic organisms: A relatively rich epibenthonic palaeofauna, formed by small azooxanthellate corals, gastropods, and brachiopods, was identified covering the unconformity surface. The presence of these fossils suggests shallower conditions than those reigning during the Late Maasrichtian. In addition, and according to Kennedy and Garrison (1975), the colonization of the surface by epizoans plus with the presence of abundant borings allows this surface to be classified as a well-developed hardground.
Fig. 6 Stromatolitic laminations in the Sierra de Aixorta condensed section observed at different scales under ransmitted light (left images) and fluorescence microscopy (right images). a-b Stromatolite accretionary subunits, characterize by a quite coarse ( $\mathrm{mm}$-scale) lamination, showing planar and domical shapes. c-d Detail of the coarse lamination of the stromatolite accretionary subunits. Each layer, defined by a single submillimetric layer, corresponds to a stromatolite elementary microunit. e-f Delicate columnar and branching phosphate microstromatolite accretions can be clearly observed (particularly in d) within the stromatolite elementary microunits. These columnar microstromatolites are surrounded by rapped carbonate deposits that include abundant planktonic foraminif era. e-f Close-up image of a delicate columnar to branching phosphate stromatolitic accretion showing internal, $\mu \mathrm{m}$-scale, laminae, reflecting successive episodes of microbial mat development

The deposits that make up the host rock of the hardground yielded the following association of planktonic foraminifera: A. mayaroensis, Contusotruncana contusa, Globotruncana conica, Racemiguembelina fructicosa, Rugoglobigerina rotundata, and Rugoglobigerina scotti. This association defines the $A$. mayroensis Interval Range Zone, which is of Late Maastrichtian age. Because of the age of the under- and overlying deposits (the stromatolitic crust, see below), the hardground must have been generated during the latest Maastrichtian-earliest Danian interval.

\section{Phases of stromatolite accretion (Early Danian-Selandian)}

The hardground surface is covered by a quite irregular, 4 10 -cm-thick microbial stromatolite crust. This crust includes both planar-laminated and columnar-laminated fabrics easily recognized in hand samples (Fig. 3e-f). The stromatolites are made up of calcium carbonate, phosphate and, to a lesser extent, iron oxides and clay minerals. The phosphate appears as amorphous masses, thin laminae, subrounded particles and phosphatic bioclasts, all attributable to francolite, a low crystallinity calcium fluorapatite which is the most common phosphate mineral that forms in the water-sediment interphase or in early diagenetic marine environments (e.g., McClellan and Van Kauwenbergh 1990; Föllmi 1996).

The stromatolites include fine biomicrite sediment, intercalated between the microbial accretions, conforming micro-to-millimetric irregular beds and patches. This carbonate deposit consists essentially of micrite and small fossil remains, and also includes some fine siliciclastic grains $(<1 \%)$ along with small, rounded and sub-rounded grains of glauconite and phosphate. The fossil content in these deposits consists of abundant, small and globular planktonic foraminifera, small, hyaline and agglutinated, deep-water, benthonic foraminifera, some fragments of echinoderms, some fish remains, small gastropods, and brachiopods. All the observed trapped sediment has a clearly open-marine, hemipelagic nature. 

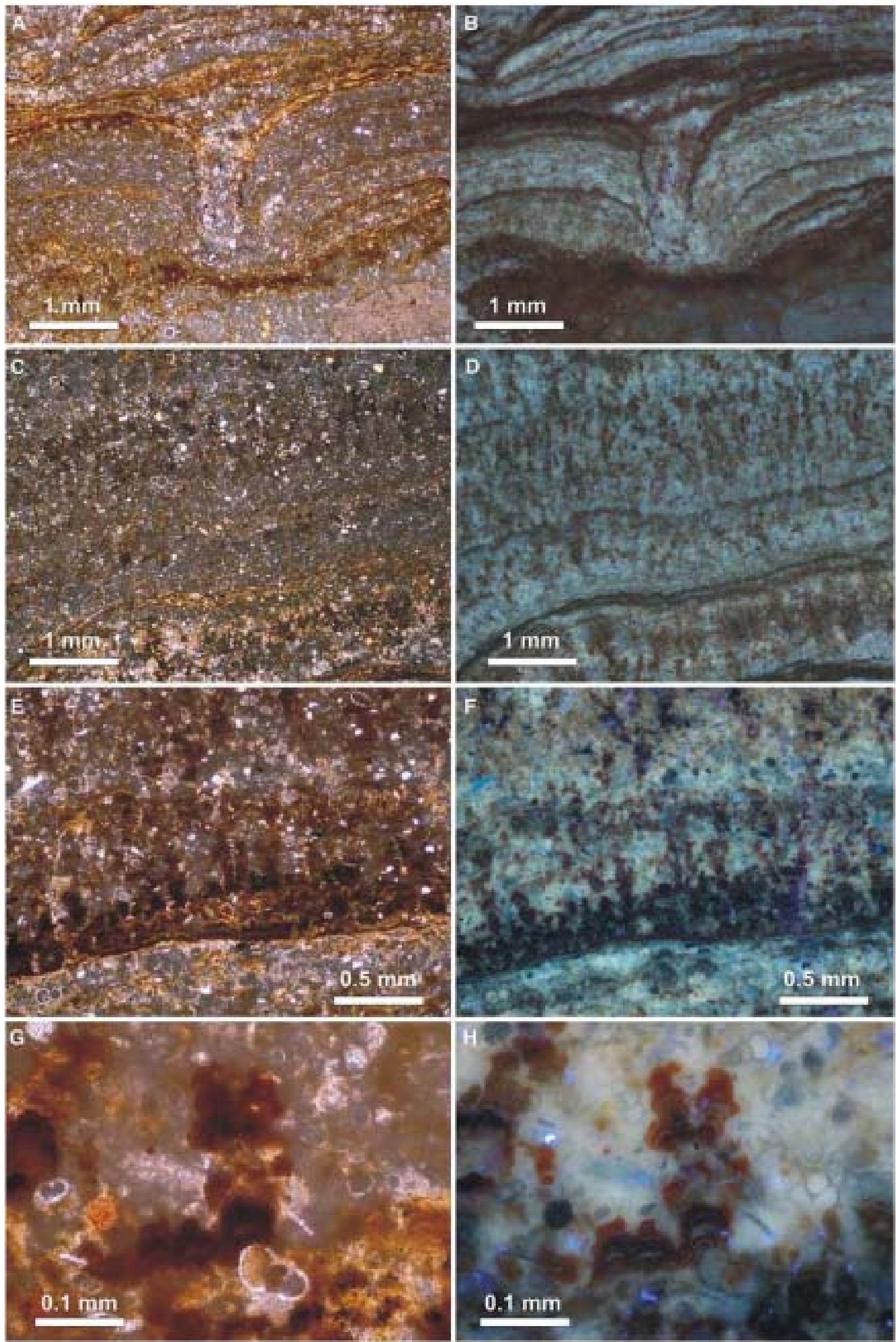
The stromatolitic accretions show a quite complex microstratigraphy consisting of different types of genetic units. We have grouped them into three hierarchical categories (Fig. 6), which from smaller to larger are stromatolite elementary microunits, stromatolite accretionary subunits and stromatolite accretionary units.

For the stromatolite elementary microunits, each microunit is define by a submillimetric layer of carbonate, phosphate and iron oxides, which results from an aggradational pulse of stromatolite growth. Internally, each microunit shows delicate domical, columnar or branching microstromatolitic structures which are surrounded by trapped biomicrite sediment in variable proportion (Fig. 6c-f). The internal architecture of each microunit reveals relevant genetic information. Many of these units (as those of Fig. 6c-f) show a net dominance of columnar and branching microstromatolitic structures (with a clear aggradational pattern), which indicates that microbial mats accreted essentially perpendicular to seafloor surface and were not able to expand laterally. This suggests "catch-up" growing conditions (Figs. 6c-h and 7a-b), in which the microbial communities try to maintain their position at the sedimentwater inter-phase, having to contend with a slightly higher biomicrite accumulation (but always at very low rates!). Only when sedimentation became extremely reduced, the microbial communities grew under "keep-up" conditions and were able of expanding laterally and generate planar and domical microstromatolites. Catch-up dominated microunits are usually thinner than keep-up ones, and are richer in phosphate and iron oxides. Internally, the phosphatic microstromatolites show a micrometer-scale lamination, defined by a delicate alternation of francolite (dominant), iron oxides, and carbonate (Fig. 7a). That fine lamination could reflect cyclic pulses in the intensity of phosphate precipitation in the microbial mat environment, related to metabolic mat activity and/or to the availability of reactive phosphate for mineral deposition (Krajewski et al. 2000). SEM images of the microstromatolite ultrastructure show a highly porous texture formed by an accumulation of spheroid, ovoid or lumping structures, sometimes densely packed, so strongly suggesting microbial activity controlling or inducing phosphate precipitation (Fig. 7c-d). All these stuctures very closely resemble those of phosphatized bacterial communities obtained in laboratory experiments (Lucas and Prévôt 1981, 1984, 1985; Prévôt and Lucas 1986; Benzeraraa et al. 2004) and also those described in examples of the fossil record (e.g., MartínAlgarra and Vera 1994; Vera and Martín-Algarra 1994; George 1999; Krajewski et a1. 2000; Martín-Algarra and Sánchez-Navas 2000).

The stromatolite accretionary subunits are up to several millimetres thick and represented by spectacular planar, domical or even columnar structures (Fig. 6a-b). These units are bounded by hiatal surfaces which are often enriched in iron oxides. Internally, they show a quite coarse lamination defined by the vertical and lateral accretion of stromatolite elementary microunits. Stacking patterns of these microunits reveals that each subunit is commonly defined by an initial set of thickening upwards microunits showing catch-up to keepup conditions, followed by a second set that show a clearly thinning upwards trend, and in which the catch-up conditions became dominant. Carbonate is more abundant in the middle (and lower) part of each subunits, whereas phosphate (and iron oxides) are usually dominant in the upper part.

The stromatolite accretionary units (SAUs) are the largest units differentiated in this analysis. They are genetic units formed by several or many subunits and defined by means of: (1) internal stratigraphy, defined by microsequence stacking patterns, mineralogical and compositional trends, and the amount and distribution of biomicrite sediment, (2) cbronos ratigraphic age, determined by the fossil content, and (3) bounding surfaces, which commonly show clear evidence of sedimentary disruption and stratigraphic gap. An important aspect for defining these stromatolite accretionary units is that each one must be easily recognizable and differentiable from the others, as well as easily traceable and correlatable. Within the Aixorta crust, we have recognize and characterized three successive SAUs. The units, in chronological order, have been named as eP1, eP2 and $\mathrm{mP}$ (Figs. 8 and 9), and their ages are respectively Early (although not earliest) to Middle Danian, Late Danian-Early Selandian and Middle Selandian. The age-dating is based on the planktonic foraminifera found trapped in the stromatolitic accretions or included in the micritic intercalations within the crust. The main features of each micro-unit are discussed in the following sections.

\section{Stromatolite accretionary unit eP1 (Early to Middle Danian)}

This basal unit coats the uppermost centime of the inner walls of the burrows and borings of the former hardground (Figs. 8a-c, 9a), and thus is constituted by cavity-dwelling stromatolites (endostromatolites, sensu Monty 1982). This phase is characterize by a net dominance of carbonate versus phosphate, and poorly defined stromatolite accretionary subunits. A broad increase in francolite and iron oxides (goethite and hematite) is however observed towards the most modern part of the unit. In this upper part, the stromatolitic subunits are better outlined and easily raceable under the microscope. The unit $\mathrm{ePl}$ was date by means of the microfossils observed in that unit. The assemblage consists of globular, small-sized, planktonic foraminifera. Their size and shape together with the absence of angular or sub-angular specimens suggest this association could be Early (although not earliest) Palaeocene in age (Early-Middle Danian). 

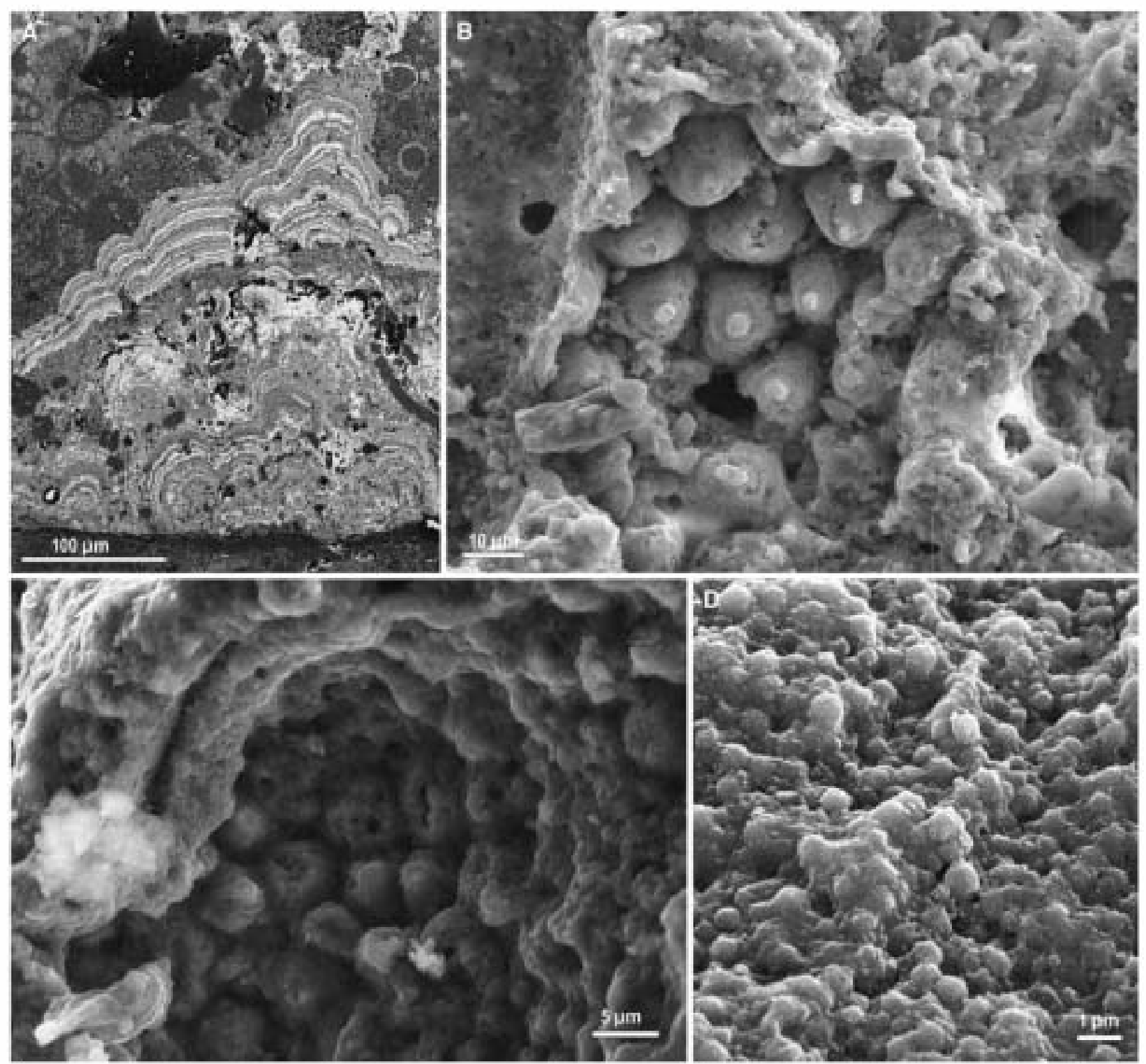

Fig. 7 SEM images of the stromatolitic crust, showing the microstructure of the phosphatic stromatolites. a Vertical polished section of microstromatolites showing internal lamination. White bands are rich in iron oxides, light grey laminae is phosphate, and the dark grey surrounding mass is bioclastic carbonate. b Mammillated upper surface of a stromatolite unit. Note that each small stromatolitic dome is characterize by a little apex reflecting the final phase of microbial mat

\section{Stromatolite accretionary unit eP2 (Late Danian-Early Selandian)}

The unit eP2 includes most of the stromatolitic subunits of the succession (Figs. 8a-c and 9a-h). It incrusts both unit $\mathrm{ePl}$ and Maas richtian carbonates, and grew both in "protected" areas (as endostromatolites, inside borings, fissures, or microcaves, extensively covering their walls, floors and roofs) and in "unrestricted" environments i.e., in the surface accretion. c Detail of $\mu \mathrm{m}$-scale hemispheric, lumping structures at the surface of a stromatolitic unit, resembling bacterial communities. d Possible microbial traces in a phosphatic stromatolite surface from unit $e P 2$. Biogenic structures shown in $\mathbf{c}$ and $\mathbf{d}$ strongly resemble phosphatized microbial communities obtained in laboratory (e.g., Prévôt and Lucas 1986) and also to those found in the Turonian of the Polish Jurassic (Krajewski et al. 2000)

of the hardground. This point is particularly interesting because it reveals the slow but progressive colonization of the sea bottom by microbial mats, and the expansion of the necessary physicochemical conditions for their development. The stromatolite accretionary unit eP2 shows a complex internal microstratigraphy in which several subunits are clearly distinguishable.

The age of unit eP2 was determined on the basis of a microfossil assemblage containing mainly globular, small- 

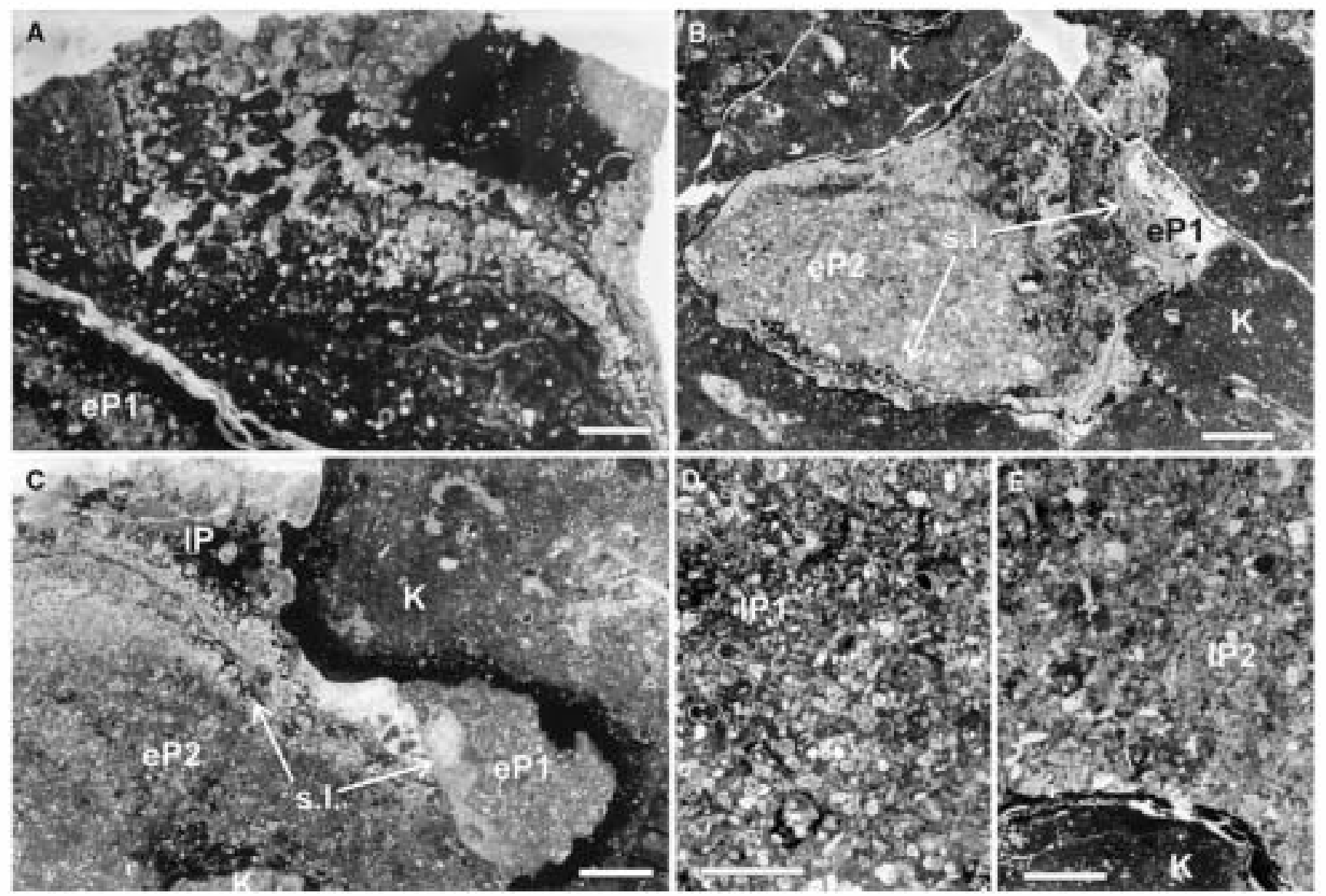

Fig. 8 Transmitted light microphotographs showing main features of the microstratigraphical units in the condensed section of Aixorta. a Planar, domical, and columnar phosphate microstromatolites at the top of unit ePI (Early Palaeocene). Small-sized, globular, planktonic foraminifers can be seen under and within the stromatolitic laminaions. b Microcavity developed in the Maastrichtian deposits $(K)$ and later filled by units $e P 1$ (Early Palaeocene in age) and $e P 2$ (Early to Middle Palaeocene in age). c Similar to $\mathbf{b}$, but also with a later infill of carbonate ( $I P$, Late Palaeocene). Note the darkening of the surface of

medium-sized planktonic foraminifers, some showing a sub-angular shape. This assemblage is characterize by the presence of the species Globanomalina compressa and Praemurica uncinata. The age assigned to unit eP2 is Late Danian-Early Selandian.

\section{Stromatolite accretionary unit $m P$ (Middle Selandian)}

This unit shows a lesser development than the former. It includes an initial phase formed by subunits dominate by biomicrite accumulation, and a later phase richer in phosphate (Fig. 8c, e). Within the whole unit, again a progressive increase in the amount of francolite has been observed towards the top.

The fossil content of unit $\mathrm{mP}$ is characterized by the presence of planktonic foraminifers of conical shape and

Maastrichtian deposits $(K)$, related to iron enrichment during hardground development. d Upper Palaeocene (Late Selandian-Early Thanetian) carbonate deposits, rich in planktonic foraminifers (with conical-shapes and sub-angular to angular periphery). e Microfacies corresponding to the last phase of condensed sedimentation (IP2, ?Middle-Late Thanetian in age), including conical-shaped planktonic foraminifers and a abundant fine clastics. Scale bar in all microphotographs: $1 \mathrm{~mm}$

angular periphery; the assemblage is dominate by specimens of the genus Morozovella (Morozovella angulata and $M$. conicotruncata were identified). SAU mP was therefore accreted during the Selandian. The relative stratigraphic position of the unit over Lower Selandian deposits and under Upper Selandian ones (see the following) indicates it has probably a Middle Selandian age. It should be noted that after $\mathrm{mP}$ there was no further remarkable stromatolite growth in the condensed succession.

Considering the three stromatolite accretionary units, it is obvious that the stromatolites started to develop in limited microenvironments, inside the borings and burrows of the previously developed hardground (Fig. 5e-f). Those were probably the zones that first reache the necessary environmental conditions for bacterial communities to develop and to induce or control authigenesis. Only after a 
Fig. 9 Microstratigraphy of the Aixorta condensed section in different samples, showing the relationships among the different genetic units. $K$ Upper Maasrichtan deposits (strongly altered by the development of the hard ground during the latest Maastrichian-earliest Danian interval). $e P 1, e P 2$, and $m P$ The three successive phosphatic stromatolite accretionary units, which respectively took place during the Early-Middle Danian, Late Danian-Early Selandian, and Middle Selandian. $I P$ Late Palaeocene deposits dominate by micrite/biomicrite condensed sedimentation (LateSelandian to ?Late Thanetian in age). a Polished section cut obliquely to the stromatolitic crust, showing the relationships among units $\mathrm{K}$, eP1, eP2, mP and $1 \mathbf{P}$. b Polished sample showing longitudinal sections of impressive columnar stromatolitic structures, corresponding to unit eP2. Observe later infill of $\mathrm{mP}$ and $\mathrm{IP}$. C Polished sample, cut obliquely to the stromatolitic crust, showing the relationships among units $\mathrm{K}$, the stromatolite accretionary units eP2 and $\mathrm{mP}$, and the later condensed deposits of $1 \mathbf{P}$, which are irregularly enriched in iron oxides. Section transversal to main stromatolite growth, showing the successive infill of the cavities previously generate in the Cretaceous sediments
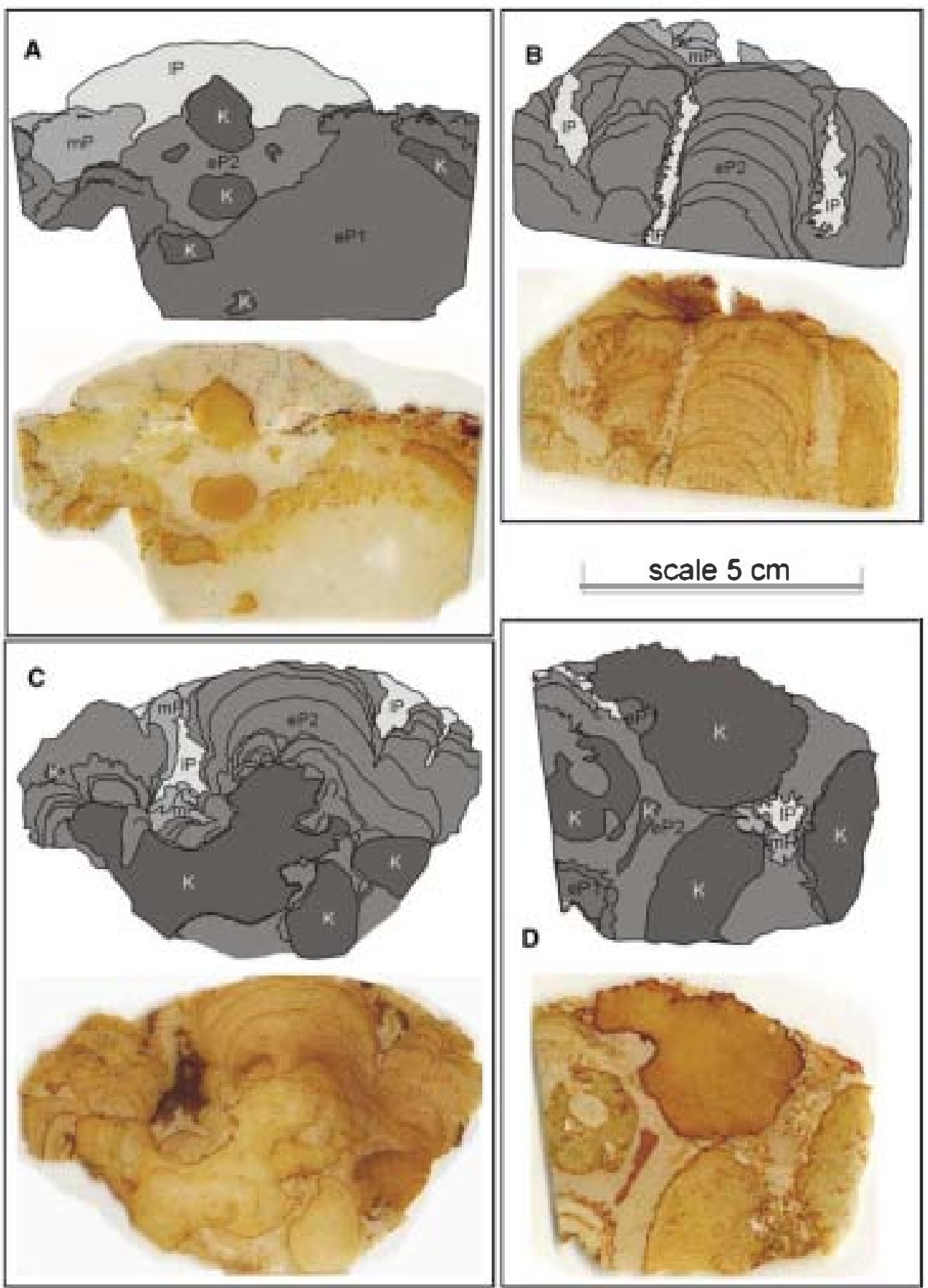

prolonged period of time, which could last up to several millions years (nearly all the Early and Middle Danian time interval), the microbial mats producing the stromatolites were able to spread outside those small, restricted microenvironments. Conditions under which the microbial mats grew should include absence of light and, according to Krajewski et al. (2000), sub-oxic to oxic waters. The relatively slow kinetics of francolite precipitation in sea bottom (Van Capellen and Berner 1991) caused this mineral only to form when sediment-accumulation rates were slow enough to permit for the transfer of substantial amounts of dissolve phosphate onto the sediment-water interface. Microbial mats activity should be critical in interstitial phosphate enrichment and phosphogenesis by means of organic matter decomposition and delivery of dissolved phosphate (e.g., Föllmi 1996). In addition, an increased influx of nutrients via upwelling currents could give an extra input of phosphorous to the sediment-water interface. During the generation of the stromatolite accretionary unit $\mathrm{mP}$, a clear recess in authigenic phosphate precipitation took place, probably related to a decrease in the phosphate availability. 
Post-stromatolite condensed deposition (Late Selandian?Late Thanetian)

An abrupt termination of phosphogenic environments took place during the Middle to Late Selandian. Sedimentation postdating the generation of the phosphatic stromatolites is still condensed, but represented by biomicrite, which completely cover the phosphatic crust (1P in Figs. 8 and 9). Locally, these sediments that cover the crust can be rich in iron oxides. Two main phases of biomicrite deposition can be differentiated:

Phase 1P1.Consists of fine biomicrite with less than $1 \%$ of very fine quartz grains, scarce sub-rounded particles of non-oxidized glauconite, and some sub-rounded phosphatic grains. It contains a very rich association of subangular to angular planktonic foraminifera, some small hyaline benthonic foraminifera, and fragments of echinoderms (Fig. 8d). The species M. conicotruncata, Globanomalina pseudomenardii, and Igorina pusilla were identified. The age of this first post-stromatolite episode is Late Selandian-Early Thanetian.

Phase 1P2. This second episode of infilling is also represented by fine biomicrite, but it includes higher proportions of quartz grains (4-6\%) of fine to medium size, and more abundant sub-rounded particles of glauconite and phosphate. The fossil assemblage of these deposits contains abundant angular-shaped planktonic foraminifera (Fig. 8e). The foraminifera assemblage includes M. velascoensis and Globanomalin pseudomenardii. These deposits are dated as Thanetian in age.

These two phases of micrite accumulation took place at very slow net rates, as indicated by biostratigraphic data. Sedimentary condensation thus continues essentially until the end of the Palaeocene. However, environmental conditions should change enough to prevent microbial mat development or, at least, phosphate precipitation.

\section{The ?latest Thanetian debris-flow event}

As indicated previously, the condensed Palaeocene sequence described in this paper was found in olistolithic blocks included in a 5-8 $\mathrm{m}$ thick chaotic bed. These blocks occur partially embedded within a soft, deformed matrix that consists of sandy packstones, rudstones, and lithoclastic microbreccias. The sandy packstones often show internal lamination and yield abundant fossil remains that reveal intense reworking and mixing. Shallow-water organisms (such as hyaline macrobenthonic planispiral foraminifers plus red algal debris), which commonly show intense sedimentary reworking and a high degree of micritization, coexist in the deposit with abundant and well-preserved planktonic foraminifers of angular shape. It is difficult to assign a precise age to the emplacement of the gravitational deposit. The younger datable fossils found in the top of the debris flow are well-preserved planktonic forms attributable to $M$. velascoensis and $M$. aequa. These fossils allow for the giving of a maximum age estimate which would lie within the Late Thanetian-Early Ilerdian interval, for the catastrophic event that caused the olistolithic blocks to fall. It should be noted here that regionally, i.e., in other areas of the Prebetic, a major tectonic event has been previously recognized and dated as latest Thanetian (De Ruig 1992; Martín-Chivelet and Chacón 2007). It seems probable that this tectonic episode caused a gravitational displacement of the seafloor in the zone previously dominated by stromatolite generation and condensed deposition, and the consequent generation of the olistolithic unit down slope in the basin.

\section{Discussion}

This study distinguished the following developmental episodes: (1) a Late Maastrichtian interval of non-condensed hemipelagic deposition; (2) a latest Maastrichtian-earliest Danian development of a mature hardground; (3) an EarlyMiddle Danian phase of initial phosphatic endostromatolite generation (eP1); (4) a Late Danian-Early Selandian phase of major stromatolite generation (eP2); (5) an in tra-Selandian (probably Middle Selandian) phase of final stromatolite development (mP); (6) a Late Selandian-Early Thanetian interval of condensed carbonate sedimentation; (7) a ?Middle to Late Thanetian interval of condensed carbonate sedimentation with noticeable terrigenous influx; and (8) the slumping event that led to the fall of the olistolith blocks during the latest Thanetian.

The inclusion of these episodes within the general developmental framework of the continental margin helps to interpret their significance. They were therefore compared and correlated with other areas of the margin of the Prebetic Zone, both basinward and landward, where the latest Cretaceous and Early Palaeogene sedimentations took place under more regular (less condensed to non-condensed) conditions. A general description of the stratigraphic patterns of the Maastrichtian-Ypresian interval in the Prebetic Zone can be found in Chacón (2002) and Martín-Chivelet and Chacón (2007).

The Late Maastrichtian sedimentation was quite homogeneous in all the hemipelagic domains of the Prebetic Zone, and dominated by the deposition of hemipelagic marls and limestones, and a few turbidite beds. These sediments correspond to the Raspay Formation and contain rich associations of planktonic and benthonic foraminifers, ostracods, and echinoids. As previously indicated, the water-depth estimate for that unit in the area, as deduced from benthonic foraminifera assemblages, is of $200 \mathrm{~m}$ or 
more (Martín-Chivelet and Chacón 2007). The uppermost Maastrichtian deposits of the Sierra de Aixorta correspond to the upper part of the Raspay Formation, and show similar features to the top of the unit in other areas.

The development of the latest Maastrichtian-earliest Danian hardground in the Sierra de Aixorta postdates a latest Maastrichtian tectonic event in the basin, which was probably conditioned by changes in intraplate stresses related to Iberian-African convergence (Martín-Chivelet and Chacón 2007). It occurred quite abruptly and induced rapid changes in local and regional subsidence, differential block movements, and variations in relative sea level (Martín-Chivelet 1996; Chacón 2002; Martín-Chivelet and Chacón 2007). Another aspect that should be considered is the K/P boundary global event, which provoked substantial modifications in environmental conditions and in the reigning biota in the margin (Canudo et al. 1991; Molina et al. 1996, 1998, 2005). The impact of that global event in the Aixorta hardground development is however difficult to evaluate with the available data.

The regional tectonic event (and probably the environmental changes induce by the K/P event) configured a new sedimentation scenario in which the considere palaeogeographic area suffered an abrupt cessation of the former hemipelagic deposition and the subsequent development of the hardground. Colonization by epibenthonic gastropods and brachiopods suggests shallower conditions than those before these events. A similar change in water depth has been recognized in other, more landward areas of the basin such as the Sierra del Carche, where a hardground also developed (Chacón and Martín-Chivelet 1999; Chacón 2002). In contrast, in the basinward direction, the water depth increased rapidly and mixed carbonate-siliciclastic hemipelagic sedimentation continued with no significant hiatus at the $\mathrm{K} / \mathrm{P}$ boundary. This is the case of the reference $\mathrm{K} / \mathrm{P}$ event sections of Agost and Caravaca (the latter in the Subbetic Zone), where the Maastrichtian-Danian transition shows a very complete record (Canudo et al. 1991; Pardo et al. 1996; Molina et al. 1996, 2005; Chacón 2002).

The conditions of non-deposition changed notably during the Early Danian in the Sierra de Aixorta. The environmental conditions necessary to allow development of epibenthonic fauna ceased, and the hardground started to become colonized by microbial mats. These first colonized internal cavities and borings, and induced the first growth of phosphatic stromatolites. A long time later, microbial mats expanded outside the restricted microenvironments and colonized the whole surface of the former hardground. The accretion of these stromatolites required very low sedimentation rates and a relevant influx of dissolved phosphorous, probably induce by the biological activity of the bacterial communities. These sedimentological and physicochemical necessary for precipitation of authigenic phos- phate were quite unique in the basin: in the rest of the area, Danian-Thanetian sedimentation was characterized by non-condensed, carbonate or mixed carbonate-siliciclastic sedimentation. Landward (e.g., towards the Sierra del Carche area; Martín-Chivelet and Chacón 2007), the K/P hardground is overlain by outer to inner shallow platform carbonates of Early (but not earliest) Danian-Late Thanetian age. Basinwards (e.g., towards the Agost area; Chacón 2002), mixed hemipelagic sedimentation continued without interruption on the latest Maastrichtian deposits, although an increase in turbidite bed production can be seen.

Palaeocene outcrops are too scarce in the Prebetic Zone for any reliable reconstruction of the platform-to-basin transition to be made. However, the differentiation experienced by the hemipelagic domains of the margin during the latest Maastrichtian-earliest Danian event suggests the generation or rejuvenation of a faint slope between the shallow domains (where shoal-reef complexes developed) and the deeper domains (that reached bathyal depths). If indeed this is the case, the stromatolite crust that today outcrops in the Sierra de Aixorta could have been generated in an area steep enough to avoid effective sedimentary accumulation of the pelagic fallout. This hypothesis would situate the development of the pelagic stromatolites somewhere in the platform to basin ansition, a quite unusual setting, as most of the examples describe in the literature are interprete as being generate in pelagic swells. The practical absence of sedimentary accumulation favoure microbial development and stromatolite accretion, the latter by means of bacterially induce precipitation of authigenic minerals.

A change in the palaeoceanographic or local environmental conditions stopped the stromatolitic growth during the Middle to Late Selandian. A similar abrupt termination of phosphogenic environments has been described at the end of the Turonian in the Polish Jurassic Chain by Krajewski et al. (2000), who interpret that cessation as the consequence of a nutrient availability decrease, related to a regional change in sea waters. As probably occurred in Aixorta, the Turonian phosphatic succession of Poland remained exposed at the seafloor during the Coniacian times, but widely represented a dead phosphatic system, over which condensed pelagic sedimentation continued.

The condensed sedimentation that postates stromatolites continued during the Late Selandian and part or all of the Thanetian. These deposits, dominated by biomicrites with variable proportions of fine siliciclastics, were generate in two main phases define by two successive genetic units. This relative increase in carbonate deposition, which occurred during the Late Selandian and over most of the Thanetian, can be correlated with a rapid expansion of carbonates in the shallow waters of the basin. In fact, the main Palaeocene phase of coral reef development took place in the shallow environments at this time (Chacón 2002). 
Despite the general evolution of the condensed section, the three accretionary phases recognized within the stromatolitic crust, and the two depositional phases differentiated within the later interval of condensed sedimentation, could be interpreted as genetic units possibly induced or controlled by changes in sea level and in other palaeoceanographic factors as primary productivity or currents. A tentative correlation with the depositional sequences recognized in other basins in Spain could throw some light on this. In particular, the five genetic micros atigraphical units and their respective ages (Early-Middle Danian, Late Danian-Early Selandian, intra-Selandian, Late SelandianEarly Thanetian, and Thanetian) tentatively correlate quite well with the five depositional sequences recognized in the Basque-Cantabrian Basin by Pujalte et al. $(1998,2000)$ and in the Pyrenees by Baceta et al. (2004). These remarkable coincidences point to a possible eustatic origin for the microunits of the condensed section or, alternatively, to another common oceanographic process affecting both basins in Iberia. Further work in the shallow-water carbonates of the Prebetic is necessary for a better understanding of the relationships between sea-level changes and the development of the units.

Finally, the submarine debris-flow event that generated by the end of the Thanetian and caused the emplacement of the olistolithic unit where today we have found that the condensed succession (in the Aixorta section) can be correlated with a regional tectonic event that generated rapid modifications in basin geometry and major changes in sedimentation with the installation of wide but relatively shallow turbidite systems (Martín-Chivelet and Chacón 2007). The event is marke in shallower areas of the Prebetic by a highly burrowe surface at the top of the Thanetian reef carbonates, which is overlain by a mixed sediment of marls and turbidites (e.g., in the Sierra del Carche section). In other areas, the tectonic event induced intense erosion, which affected part or all of the Upper Maastrichtian and Palaeocene records (e.g., in the Sierra de Maigmó and near the town of Aspe, see Fig. 1 for location). This regional tectonic event is interpreted as being related to contractional stresses within the framework of the convergence of Europe, Iberia and Africa.

From a broader palaeoceanographic perspective, the characterization of the Palaeocene condensed section in the Sierra Aixorta shows that the oceanographic conditions that favoured the development of deep-water phosphatic stromatolites during the Jurassic and the Cretaceous in the Western Tethys prevailed, at least locally, unaltered during most of the Palaeocene, despite the environmental changes associated with the K/P global event. The studied condensed succession contains probably the youngest known example of well-developed phosphatic pelagic stromatolites in the Western Tethys, suggesting that the conditions that controlle the development of these striking formations did not survive the changes that occurred in the global ocean-climate system during the end of the Palaeocene.

\section{Conclusions}

A 6-15-cm-thick very condensed and phosphatized pelagic succession was developed during the latest Maastrichtian, and essentially throughout the Palaeocene, in an area that probably occupied an intermediate position between the shallow-water (carbonate platform) and deeper pelagic environments of the ancient southern continental margin of Iberia. Condensed sedimentation lasted about $9 \mathrm{Ma}$, and passed through six successive stages represented by a basal, well-developed hardground (latest Maastrichtian-earliest Danian in age) and five microstratigraphical genetic units dated by the inspection of their planktonic foraminifera (respectively Early-Middle Danian, Late Danian-Early Selandian, intra-Selandian, Late Selandian-Early Thanetian, and Middle to ?Late Thanetian in age). The three oldest units are characterized by the accretion of phosphate stromatolites, which was favoure by very low rates of pelagic particle accumulation and probably by the extra influx of phosphate, iron and other elements. The two youngest units are dominated by micrite/biomicrite accumulation, which also took place at very low rates. During the genesis of the condensed succession, palaeoceanographic changes, as variations in sea level, primary productivity and/or currents, could control the development of the microstratigraphical units and their bounding surfaces.

The development of the deep-water stromatolites occurred in three main phases within a relatively continuous process (but punctuated by multiple accretionary phases) throughout a time interval lasting 4-5 Ma. Its prolonged development is interpreted to be related to the generation and maintenance of necessary environmental conditions, which are not only determined by a favourable depositional and oceanographic setting, but also by the microbial mat itself, which prepares and controls the physicochemical conditions for their own survival and expansion.

The detailed study of these condensed successions can provide rich information about basin evolution and palaeogeography, especially when coetaneous non-condensed sections are scarce and incomplete. This is the case of the Palaeocene in the Prebetic Zone, which is well exposed only in a few outcrops. This study reveals five successive episodes of sedimentation that took place in an interval of relative tectonic quiescence (between two regional, relatively abrupt, tectonic events), and probably controlled by sea-level changes. This is the first time such a description has been made for the Palaeocene in this continental margin. 
The environmental conditions necessary for pelagic, phosphatic, stromatolite development in the western Tethys Ocean reigned not only during the Jurassic and Cretaceous, but also throughout the Palaeocene, despite the oceanographic changes related to the $\mathrm{K} / \mathrm{P}$ global event. These conditions probably altered, however, with the changes that occurred by the end of the Palaeocene.

Acknowledgements This paper is a contribution to the Spanish Ministry of Education and Science project CGL2005-06636-C02-02/BTE, and of the Paleoclimate and Global Change Research Group of the Universidad Complutense-Comunidad de Madrid (910198). The authors appreciate the collaboration of Prof. X. Orue-Etxebarria (Basque Country University) for his guidance in the study of planktonic foraminifera. Adrian Burton is acknowledged for the careful editing of the English manuscript. SEM and EPMA analyses were made in the Centro de Microscopía at the UCM. Thanks are extended to editor Andre Freiwald and two anonymous referees for constructive comments and criticisms on the manuscript.

\section{References}

Baceta JI, Pujalte V, Bernaola G (2004) El Maastrichtiense final, Paleoceno e Ilerdiense inferior de la Cordillera Pirenaica. In: Vera JA (ed) Geología de España. Sociedad Geológica de España, Instituto Geológico y Minero de España, Madrid, pp 308-313

Benzeraraa K, Menguya N, Guyota F, Skouri F, Lucab G, Barakatb M, Heulinb T, (2004) Biologically controlled precipitation of calcium phosphate by Ramlibacter tataouinensis. Earth Planet Sci Lett 228:439-449

Böhm F, Brachert TC (1993) Deep-water stromatolites and Frutexites MASL V from the Early and Middle Jurassic of S-Germany and Austria. Facies 28: 145-168

Canudo JI, Keller G, Molina E (1991) Cretaceous/Tertiary boundary extinction pattern and faunal tumover at Agost and Caravaca, SE Spain. Mar Micropaleontol 17:319-341

Chacón B (2002) Las sucesiones hemipelágicas del final del Cretácico e inicio del Paleógeno en el SE de la Placa Ibérica: Estratigrafía de eventos y evolución de la cuenca. PhD Thesis, Universidad Complutense, Madrid, $439 \mathrm{pp}$

Chacón B, Martín-Chivelet J (1999) El Cretácico terminal y paleoceno de la Sierra del Carche (dominio prebético, Jumilla) Caracterización estratigráfica y sedimentológica. Geogaceta 26:12-14

Chacón B, Marún-Chivelet J (2005) Subdivisión litoestratigráfica de las series hemipelágicas de edad Coniaciense - Thanetiense en el Prebético oriental (SE de España). Rev Soc Geol Esp 18:3-20

Chacón B, Martín-Chivelet J, Graefe KU (2004) Latest Santonian to latest Maastrichtian planktic foraminifera and biostratigraphy of the hemipelagic series of the Prebetic (Murcia and Alicante provinces, SE Spain). Cretac Res 25:585-601

Company M, García-Hernández M, López Garrido AC, Vera JA, Wilke H (1982) Interpretación genética y paleogeográfica de las turbiditas y materiales redepositados del Senoniense superior en la Sierra de Aixorta (Prebético Interno, Provincia de Alicante). Cuad Geol Iber 8:449-463

De Ruig MJ (1992) Tectono-sedimentary evolution of the Prebetic fold belt of Alicante (SE Spain). PhD Thesis, Free University, Amsterdam, $207 \mathrm{pp}$

Föllmi KB (1989) Evolution of the Mid-Cretaceous triad: Platform carbonates, phosphatic sediments, and pelagic sediments along the Northern Tethys Margin. Lecture Notes of Earth Science 23, Springer, Berlin, $153 \mathrm{pp}$
Fölhni KB (1996) The phosphorus cycle, phosphogenesis and marine phosphate-rich deposits. Earth Sci Rev 40:55-124

George AD (1999) Deep-water stromatolites, Canning Basin, northwestern Australia. Palaios 14:493-505

Kennedy W J, Garrison RE (1975) Morphology and genesis of nodular chalks and hardgrounds in the Upper Cretaceous of southern England. Sedimentology 22:311-386

Krajewski KP, Van Capellen P, Trichet J, Kuhn •, Lucas J, MartínAlgarra A, Prêvot L, Tewari VC, Gaspar L, Knight RI, Lambody M (1994) Biological processes and apatite formation in sedimentary environments. Eclogae Geol Helv 87:701-745

Krajewski KP, Lesniak PM, Lacka B, Zawidzki P (2000) Origin of phosphatic stromatolites in the Upper Cretaceous condensed sequence of the Polish Jura Chain. Sediment Geol 136:89-112

Lucas J, Prévôt L (1981) Synthèse de l'apatite à partir de matière organique phosphorée (ARN) et de calcite par voie bactérienne. C R Acad Sci Paris II 292:1203-1208

Lucas J, Prévôt L (1984) Synthèse de l'apatite à partir de matière organique et de divers carbonates de calcium dans des eaux douce et marine naturelles. Chem Geol 42:101-118

Lucas J, Prévôt L (1985) The synthesis of apatite by bacterial activity: a mechanism. In: Lucas J, Prevôt L (eds) Phosphorites. Mém Sci Géol Fr 77:83-92

Marún-Algarra A, Vera JA (1994) Mesozoic pelagic phosphate stromatolites from the Penibetic (Betic Cordillera Southem Spain). In: Bertrand-Sarfati J, Monty C (eds) Phanerozoic Stromatolites II, vol II. Kluwer, Dordrecht, The Netherlands, pp 345-391

Martín-Algarra A, Sánchez-Navas A (1995) Phosphate stromatolites from condensed cephalopod limestones, Upper Jurassic, southern Spain. Sedimentology 42:893-919

Marún-Algarra A, Sánchez-Navas A (2000) Bacterially mediated authigenesis in Mesozoic stromatolites from condensed pelagic sediments (Betic cordillera, southern Spain). In: Glenn CR, PrévôtLucas L, Lucas J (eds) Marine authigenesis: from global to microbial. SEPM Spec Publ 66:499-525

Marún-Chivelet J (1994) Litoestratigrafía del Cretácico superior del Altiplano de Jumilla-Yecla (Zona Prebética). Cuad Geol Iber 18:117-173

Marun-Chivelet J (1996) Late Cretaceous subsidence history of the Betic Continental Margin (Jumilla-Yecla Region, SE Spain). Tectonophysics 265:191-211

Marún-Chivelet J, Chacón B (2007) Event-stratigraphy of the Upper Cretaceous to Palaeocene hemipelagic sequences of the Prebetic: the record of tectonic convergence in a passive continental margin. Sediment Geol 197:141-163

Martín-Chivelet J, Berástegui X, Rosales I, Vera J., Vilas L, Caus E, Gräfe K-U, Segura M, Puig C, Mas R, Robles S, Floquet M, Quesada S, Ruiz-Ortiz PA, Fregenal-Martínez MA, Salas R, GarcíaA, Martín-Algarra A, Arias C, Meléndez N, Chacón B, Molina JM, Sanz JL, Castro JM, García-Hernández M, Carenas B, García-Hidalgo J, Gil J, Ortega F (2002) Cretaceous. In: Gibbons W, Moreno T (eds) Geology of Spain. Geological Society of London, pp 255-292

McClellan GH, Van Kauwenbergh SJ (1990) Mineralogy of sedimentary apatites. In: Notholt AJG, Jarvis I (eds) Phosphorite research and development. Geol Soc Lond Spec Publ 52:23-31

Molina E, Arenillas I, Arz JA (1996) The Cretaceous/Tertiary bound ary mass extinction in planktonic foraminifera at Agost (Spain). Rev Micropaleontol 39:225-243

Molina E, Arenillas I, Arz JA (1998) Mass extinction in planktic foraminifera at the Cretaceous/Tertiary boundary in subropical and temperate latitudes. Bull Soc Geol Fr 169:351-363

Molina E, Alegret L, Arenillas I, Arz JA (2005) The Cretaceous/ Paleogene boundary at the Agost section revisited: paleoenvironmental reconstruction and mass extinction pattern. J Iber Geol 31:135-150 
Monty CLV (1982) Cavity or fissure dwelling stromatolites (endostromatolites) from Belgian Devonian mud mounds. Ann Soc Geol Belg 105:343-344

Pardo A, Ortiz N, Keller G (1996) Latest Maastrichtian and Cretaceous-Tertiary boundary foraminiferal tumover and environmental changes at Agost, Spain. In: MacLeod N, Keller G (eds) The Cretaceous-Tertiary mass extinction: biotic and environmental events. Norton, New York, pp 139--171

Prévôt L, Lucas J (1986) Microstructure of apate replacing carbonate in synthesized and natural samples. J Sediment Petrol 56:153-159

Pujalte V, Baceta JI, Orue-Etxebarría X, Payros A (1998) Paleocene strata of the Basque County, western Pyrenees, northern Spain: facies and sequence development in a deep-water starved basin. In: De Gracianski PC, Hardenbol J, Jacquin T, Vail PR (eds)
Mesozoic and Cenozoic sequence stratigraphy of European basins. SEPM Spec Publ 60:311-325

Pujalte V, Robles S, Orue-Etxebaría X, Baceta JI, Payros A (2000) Uppermost Cretaceous-Middle Eocene strata of the Basque Cantabrian region and western Pyrenees: a sequence stratigraphic perspective. Rev Soc Geol España 13:191-211

Sánchez-Navas A, Marún-Algarra A (2001) Genesis of apatite in phosphate stromatolites. Eur J Mineral 13:361-376

Van Capellen P, Berner RA (1991) Fluorapatite crystal growth from modified seawater solutions. Geochim Cosmochim Acta 55:1219-1234

Vera JA, Martín-Algarra A (1994) Mesozoic stratigraphic breaks and pelagic stromatolites in the Betic Cordillera, southern Spain. In: Bertrand-Sarfati J, Monty C (eds) Phanerozoic stromatolites II, vol II. Kluwer, Dordrecht, The Netherlands, pp 319-344 